\title{
20. CONE-IN-CONE AND BEEF-IN-SHALE TEXTURES FROM DSDP SITE 330, FALKLAND PLATEAU, SOUTH ATLANTIC
}

\author{
John Tarney, Department of Geological Sciences, The University of Birmingham B15 2TT \\ and \\ B. Charlotte Schreiber, Department of Earth and Environmental Sciences, \\ Queens College, CUNY, Flushing, NY 11367
}

\section{INTRODUCTION}

Sediments of Late Jurassic to Early Cretaceous age, overlying a continental gneissic basement, were sampled in fifteen cores at Site 330, Falkland Plateau. Thin limestone bands occur at intervals throughout much of the succession represented by Cores 3 through 14 . Many of the limestones, which vary in thickness from two or three centimeters to several tens of centimeters, are characterized by secondary recrystallization features commonly known as "cone-in-cone" and "beef-in-shale." These features are particularly well developed in some of the limestone bands of Oxfordian-Kimmeridgian age between Cores 5 and 10 where the intervening olive-black sapropelic claystones have a relativley high organic carbon content (ca 5\%).

We record some of the textural relationships observed and comment briefly on their origin. Samples for petrographic examination were prepared by smooth grinding the split core sections and etching them with dilute acid to accentuate the shale partings. Some of the more interesting features were later studied in thin section.

\section{MACROSCOPIC FEATURES}

The best developed cone-in-cone structures occur in Core Section 330-5-1. Figure 1 shows a section across one side of a major cone structure with an apical angle close to $60^{\circ}$. The prominent partings separating individual cones are filled with soft clay, but thinner clay partings mark smaller parasitic cones. Ribbing features along the major partings are characteristic of cone-incone structures (Pettijohn, 1975, fig. 12-8). Those in Core Section 330-5-1 seem to be about the same amplitude as the minor parasitic cones. Note that the ribbing is more pronounced where the clay infilling is thickest (Figure 1).

Variations in the size and degree of development of cone-in-cone structure is seen in individual limestone layers. Figure 2, from Core Section 330-10-1, for instance shows how cone structures develop progressively from horizontally laminated shaly limestone upwards through a layer of cones of small amplitude to a layer of essentially fibrous calcite over a distance of less than 5 $\mathrm{cm}$. Thin layers of fibrous calcite similar to the latter occur within the dominantly shaly parts of the succession ("beef in shale," Lang et al., 1923). One such band, no more than $4 \mathrm{~cm}$ thick is illustrated in Figure 3 (Core Section 330-8-3). Here the vertically oriented fibrous calcite has displaced the shale partings into small cone structures.

While the above examples are ones in which the cones, though variably developed, are of right circular type, the relationships exhibited in Core Section 33011-6 (Figures 4 and 5) are more complex. Most of the shale partings are angled steeply to the bedding planes, but the cone forms are not. In fact there is an almost conjugate style in the arrangement of the cone axes in this segment. The shale laminae are developed more prominently on the most steeply inclined cone surface, where the cone axes themselves are inclined, but they show equal development where the cone axes are vertical (Figure 5).

The cone-in-cone section of Core Section 330-11-6 (Figure 4) abuts sharply against horizontally laminated calcareous shale at its lower boundary. While this could be accounted for as a drilling phenomenon, the cone features at the upper boundary are also truncated (Figure 4), superficially resembling an unconformity. There is however a marked change in mineralogy and composition at this boundary. A thin horizontal vein of fibrous calcite is also present in the cone-in-cone section immediately below this boundary.

\section{PETROLOGY}

Where the cone features are best developed, as in Core Section 330-5-1, thin sections reveal that the cones are made up of coarse grained aggregates of fibrous calcite crystals (Figure 6). The acicular calcite crystals are arranged in conical bundles, microscopically reflecting the megascopic cones themselves (see also Franks, 1969; Kendall and Simpson, 1974). Shale laminae are located between the conical crystal aggregates and appear to have been deformed into conical shapes during growth of the calcite crystals.

The same features are apparent in Core Section 33011-6, but here (Figure 7) the acicular calcites are finer grained and arranged in plumose crystal aggregates. Above the discontinuity at the upper limit of the conein-cone structures in Core Section 330-11-6, the fine grained rock is composed of small scalenohedral calcite crystals of calcite in a matrix of amorphous siderite (Figure 8). Clearly this rock has crystallized in a completely different way from that immediately below where the calcite is intermixed with shale. Kendall and Simpson (1974) noted that, in the Upper Cretaceous succession in Saskatchewan, fibrous calcite only developed in association with layers of bentonite clay. 


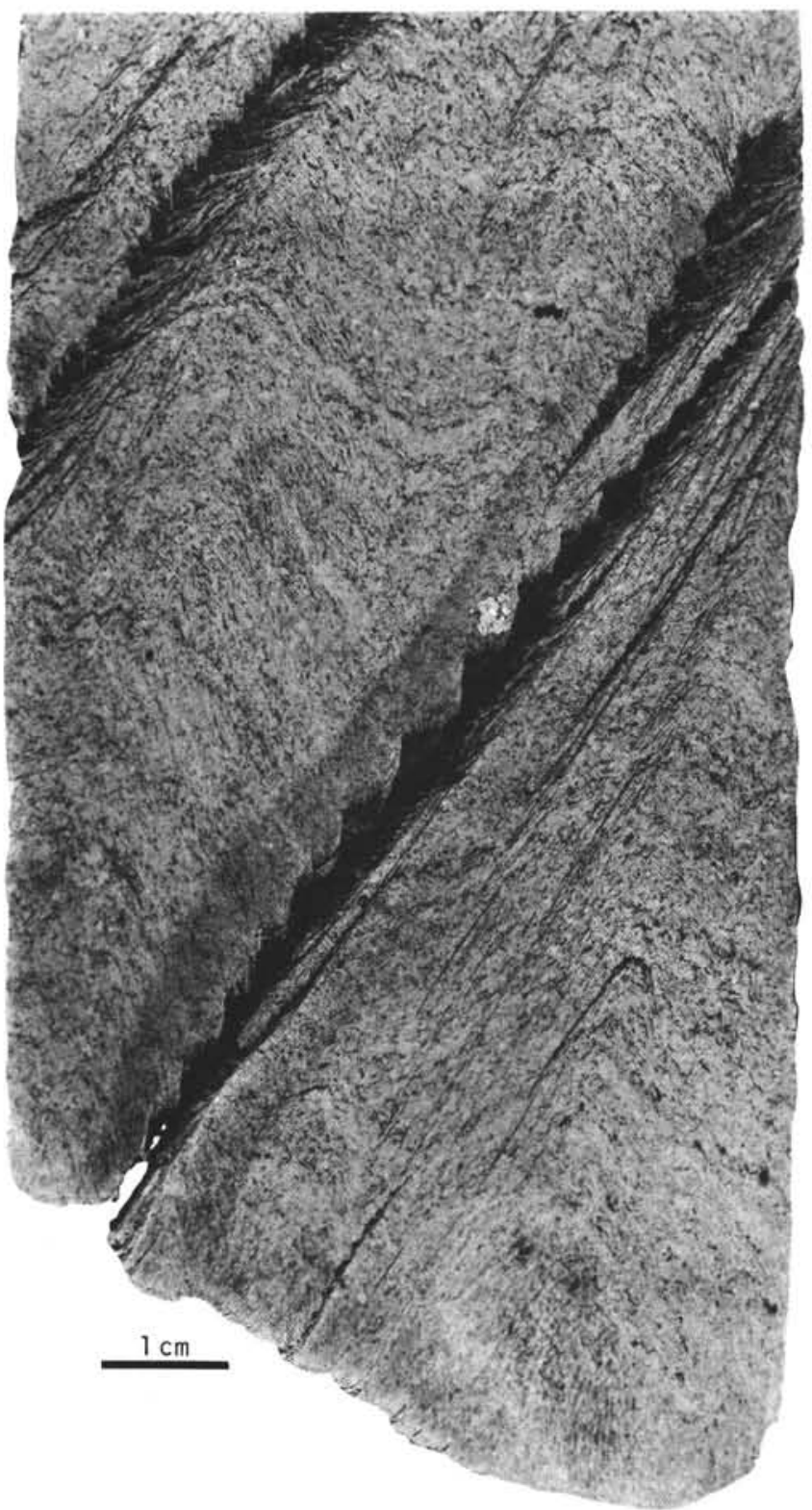

Figure 1. Sample 330-5-1, 14-28 cm. Well developed conein-cone structure in shaly limestone. Diagonal surfaces between major cone features were filled with soft clay before grinding and etching.

In the calcite vein of Core Section 330-11-6, the crystals are aligned perpendicular to the margin of the vein (Figure 9), and span at least half the width of the vein, although those at the actual margin of the vein are much finer grained. The calcite vein seems to have developed rather later than the cone structures, but may have formed under similar conditions. Laterally the vein dies out through a zone of smaller calcites where it approaches the calcite-siderite band.

\section{DISCUSSION}

Cone-in-cone structures were discussed by Richardson (1923) but have been reviewed by Tarr (1932) and

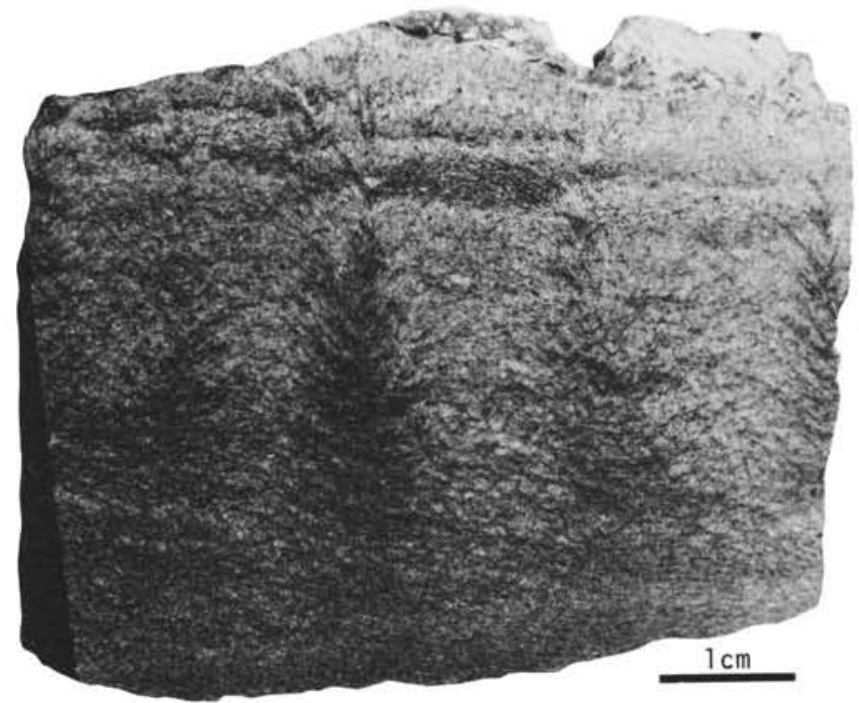

Figure 2. Sample 330-10-1, 79-84 cm. Cone-in-cone structure developing between horizontally laminated shaly limestone (base) and fibrous calcite (top).

more comprehensively by Woodland (1964). Both cone-in-cone and "beef-in-shale" are characterized by fibrous calcite. It has been established that the fibrous calcite is not part of the original beds but is a postdepositional phenomenon (Brown, 1954; MacKenzie, 1972; Kendall and Simpson, 1974; Pettijohn, 1975). Comparisons have been drawn in fact with the fibrous habit of gypsum in gypsum veins. Shearman et al. (1972), in a study of fibrous gypsum veins, postulated hydraulic jacking and fracture as the cause of the fibrous vein emplacement and crystallization, perhaps related to the volume change between anhydrite and gypsum. The equivalent volume change between aragonite and calcite, however, is much smaller.

Tarr (1932) suggested that the stresses giving rise to the fibrous calcite in cone-in-cone were attributable to loading and overburden. Woodland (1964) thought that the structures were more directly related to the crystal growth habit itself. Kendall and Simpson (1974) however noted the formation of acicular calcite immediately beneath layers of bentonite clay, and suggested that the lateral stresses which produced the conical aggregates were a result of crystal growth itself where calcite had been introduced. In the present case too it would seem that many, but not necessarily all, of the limestone layers in this part of the succession could be a result of postdepositional redistribution of calcite. All the layers of fibrous calcite or cone-in-cone are associated with clay.

The best developed cone-in-cone structures in the Falkland Plateau sediments occur within Upper Jurassic dark sapropelic claystones with a high organic content, thought to have been deposited under euxinic conditions (Thompson, this volume). Euxinic sedimentation was apparently widespread in the South Atlantic, and in the North Atlantic too, during Late JurassicEarly Cretaceous times (Hollister, Ewing, et al., 1972; Bolli, Ryan, et al., 1975; Lancelot, Seibold, et al., 1975) 


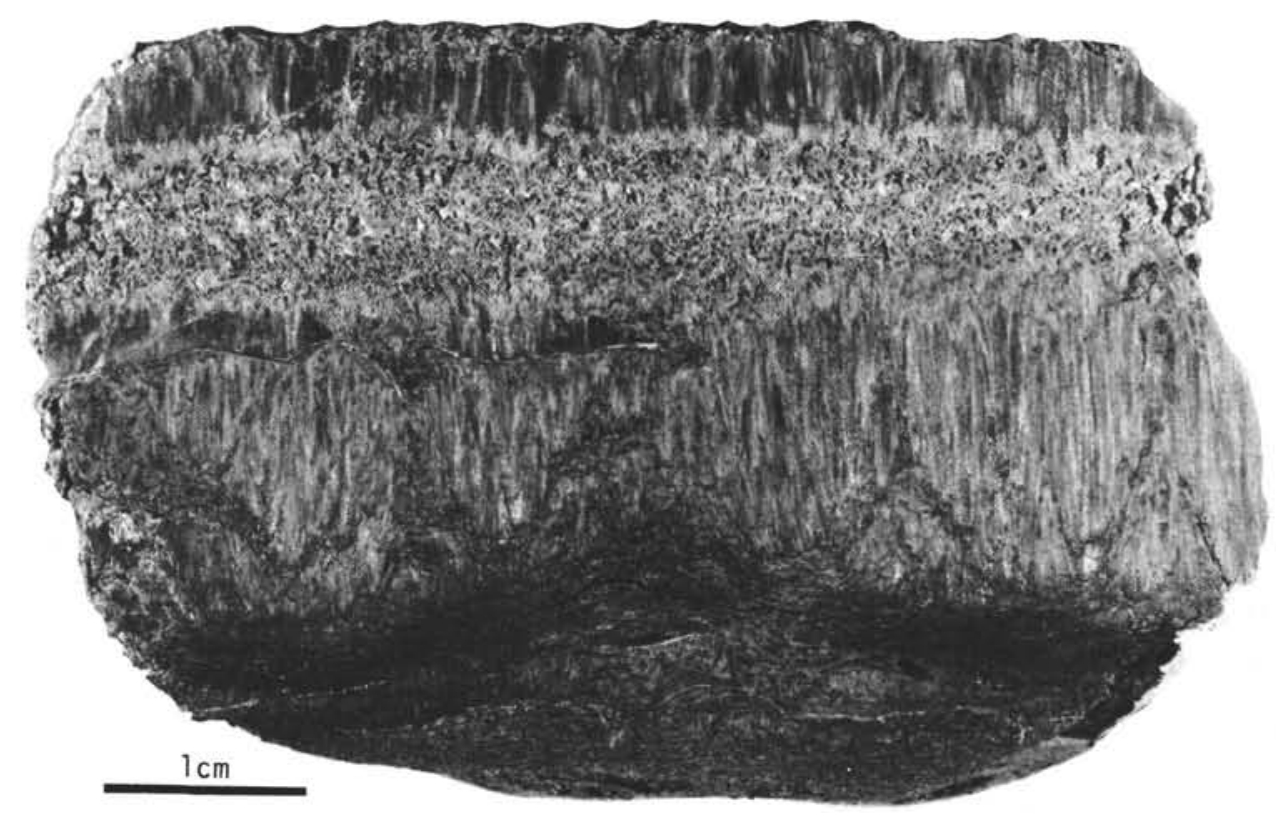

Figure 3. Sample 330-8-3, 130-133 cm. "Beef-in-shale" layer of fibrous calcite developed from calcareous shale. Note displacement of shale laminae by successive layers of calcite crystals.

perhaps related in some way to the initial fragmentation of Gondwanaland. Mackenzie (1972) noted the association of fibrous calcite layers with bituminous shale in Middle Devonian sediments from Northern Canada. At Site 330 the cone-in-cone structures are not found below Core 11, where the terrigenous component in the sediments is higher, nor in the Aptian-Albian sediments above Core 5 where the proportion of calcium carbonate in the sediments is higher overall. In summary, while fibrous calcite and cone-in-cone development are linked with calcareous clay-rich sediments, the association with carbonaceous clays at Site 330 may be coincidental. On the other hand, if, as suggested by Kendall and Simpson (1974), permeability is an important factor in the concentration and secondary growth of calcite, the high content of organic matter may well have influenced permeability.

\section{REFERENCES}

Bolli, H.M., Ryan, W.B.F., et al., 1975. Basins and margins of the eastern South Atlantic: Geotimes, v. 20 (5), p. 2224.

Brown, R., 1954. How does cone-in-cone material become emplaced? Amer. J. Sci., v. 252, p. 372-376.

Franks, P.C., 1969. Nature, origin and significance of conein-cone structures in the Kiowa Formation (Early
Cretaceous), north-central Kansas. J. Sed. Petrol., v. 39, p. 1438-1454.

Hollister, C.D., Ewing, J.I., et al., 1972. Initial Reports of the Deep Sea Drilling Project, Volume 11: Washington (U.S. Government Printing Office), p. 1077.

Kendall, A.C. and Simpson, F., 1974. Calcite layers in the uppermost Medicine Hat Sandstone (Upper Cretaceous) of Southwestern Saskatchewan. Bull. Can. Petrol. Geol., v. 22 , p. $34-41$.

Lancelot, Y., Seibold, E., et al., 1975. The eastern North Atlantic. Geotimes, v. 20 (7), p. 18-21.

Lang, W.D., Spath, L.F., and Richardson, W.A., 1923. Shales-with-beef sequence in the Lower Lias of the Dorset coast. Quart. J. Geol. Soc. Lond., v. 79, p. 47-98.

Mackenzie, W.S., 1972. Fibrous calcite, a Middle Devonian geological marker, with stratigraphic significance, District of Mackenzie, Northwest Territories. Can. J. Earth Sci., v. 9, p. 1431-1440.

Pettijohn, F.J., 1975. Sedimentary Rocks (3rd edition), New York (Harper and Row), 628 p.

Richardson, W.A., 1923. Petrology of the shales with "beef." Quart. J. Geol. Soc. Lond., v. 79, p. 88-94.

Shearman, D.J., Mossop, G., Dunsmore, H., and Martin, M., 1972. Origin of gypsum veins by hydraulic fracture. Trans. Inst. Mining Metallurgy (sect. B), v. 181, p. 149155.

Tarr, W.A., 1932. Cone-in-cone. In Twenhofel, W.H. (Ed.), Treatise on sedimentation. Williams and Wilkins, Baltimore, p. 716-733.

Woodland, B.C., 1964. The nature and origin of cone-in-cone structure. Fieldiana Geology, v. 13, p. 187-305. 
J. TARNEY, B. L. SCHREIBER

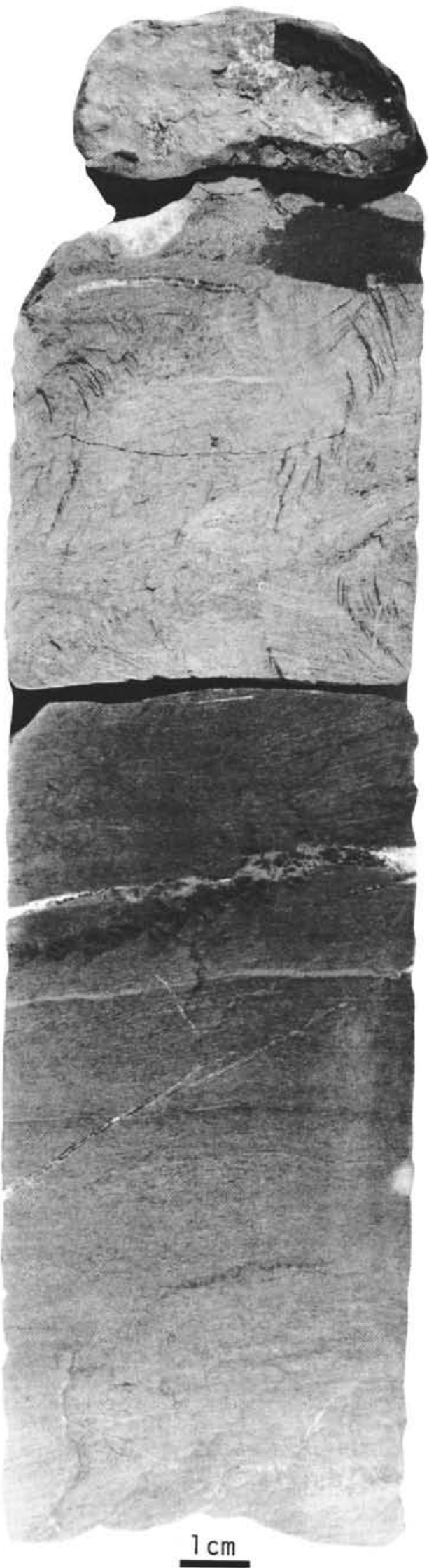

Figure 4. Sample 330-11-6, 127-150 cm. Cone-in-cone structures well developed in shaly limestone (upper part) but not developed where shale component is higher (lower zone). 


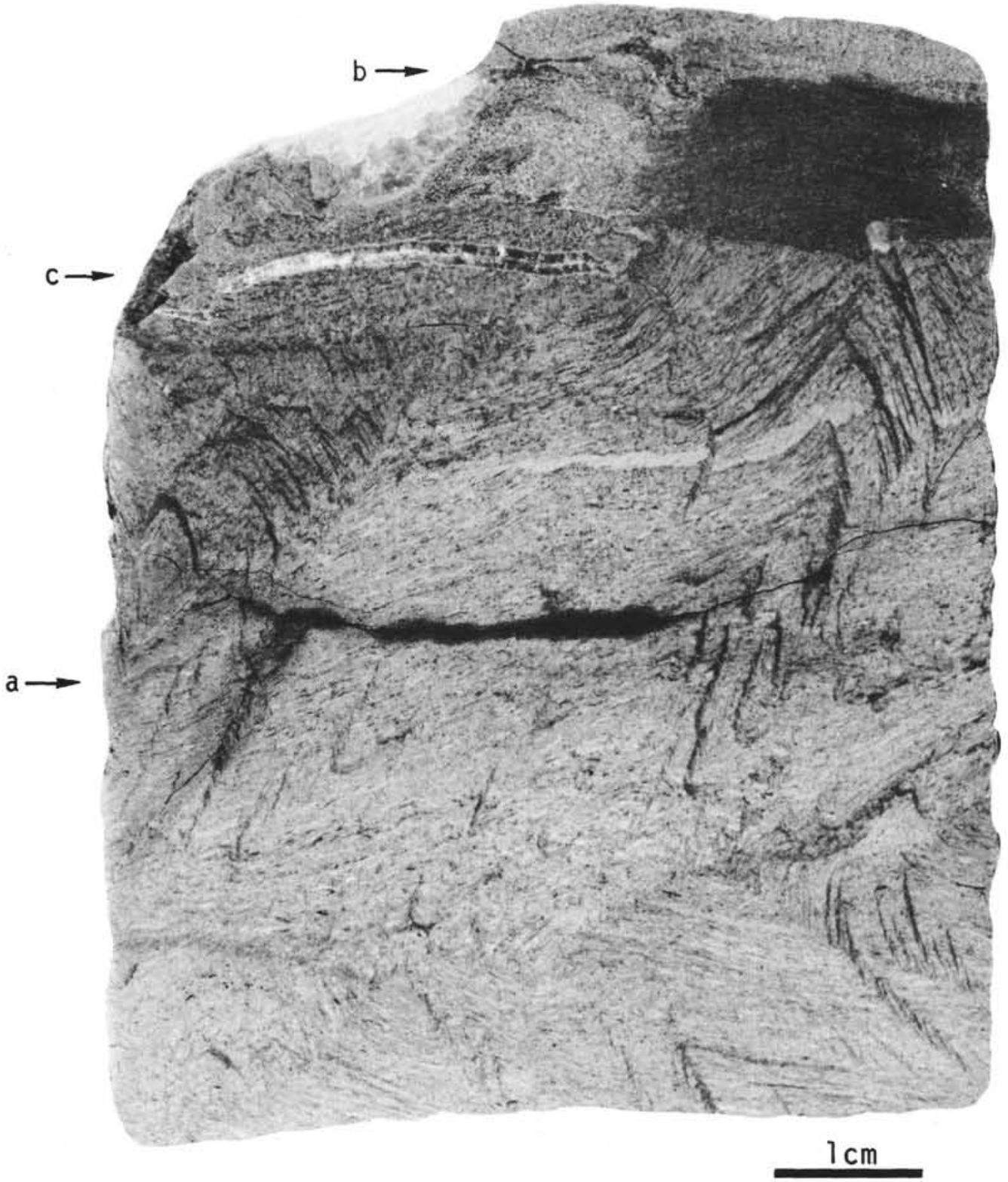

Figure 5. Sample 330-11-6, 130-137 cm. Detail of upper part of Figure 3, sample polished and etched. (a) Well developed cone-in-cone with shale partings displaced and distorted by secondary growth of fibrous calcite. (b) Zone of small scalenohedral calcites in siderite matrix unaffected by cone-in-cone development. (c) Later fibrous calcite vein. 


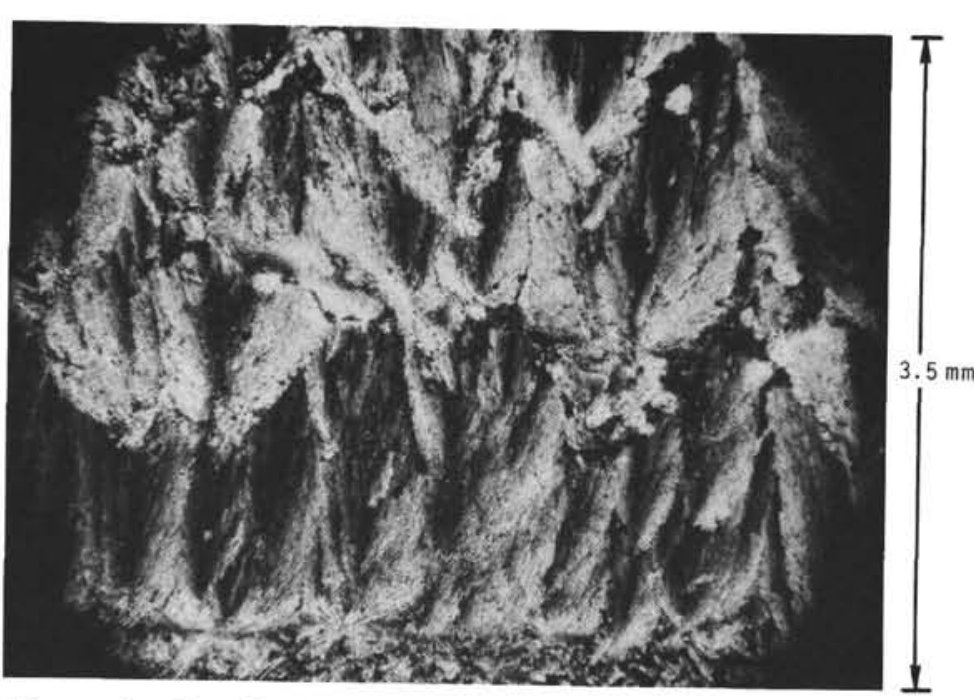

Figure 6. Sample 330-5-1, 14-28 cm. Photomicrograph showing coarse conical crystal aggregates of fibrous calcite in cone-in-cone structure.

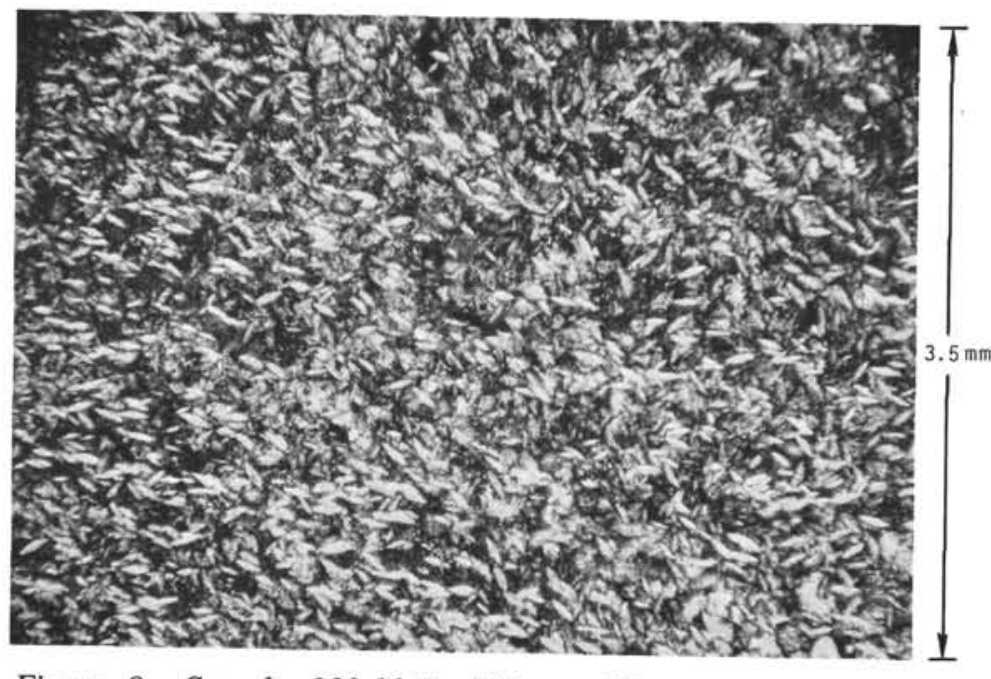

Figure 8. Sample 330-11-6, $130 \mathrm{~cm}$. Photomicrograph of fine grained upper zone (b) in Figure 5. Small scalenohedral calcites (0.1-0.15 mm in length) in amorphous siderite matrix.

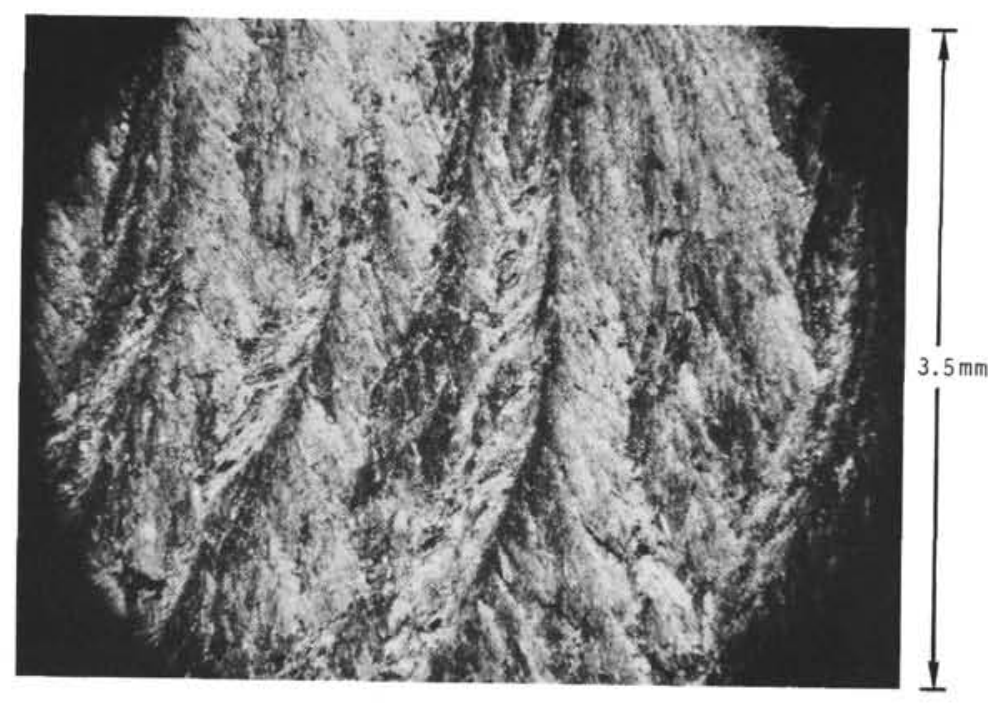

贷

Figure 7. Sample 330-11-6, 130-137 cm. Photomicrograph showing finer grained feathery aggregates in fibrous calcite.

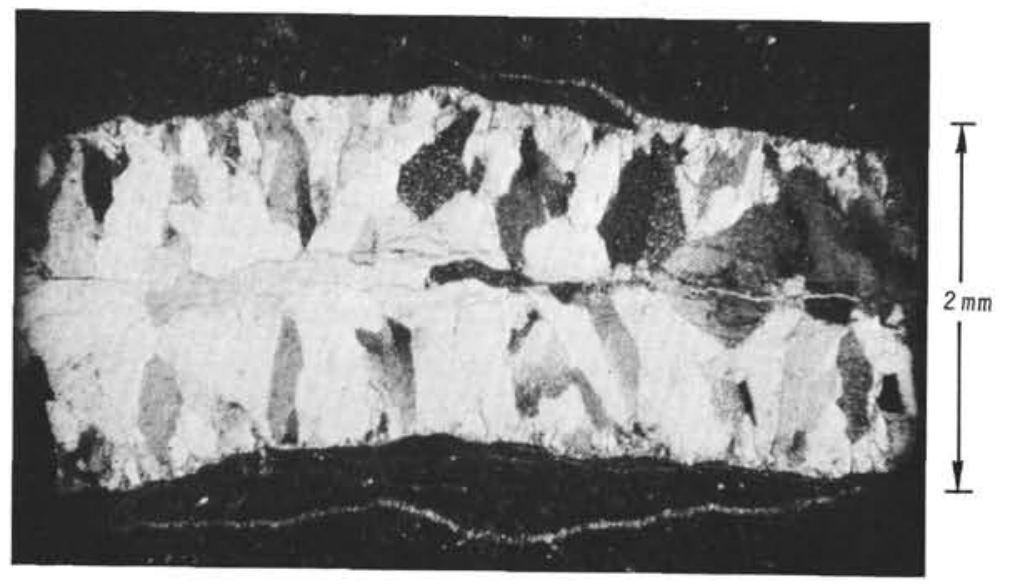

Figure 9. Sample 330-11-6, $132 \mathrm{~cm}$. Photomicrograph of small calcite vein (c) in Figure 5. 